\title{
Klasifikasi Rendaku Dalam Buku Basic Kanji Volume I Dan Volume II
}

\author{
Menik Diah Wardani*, Idah Hamidah, Hartati \\ Program Studi Sastra Jepang, Universitas Jenderal Soedirman, Purwokerto, Indonesia
}

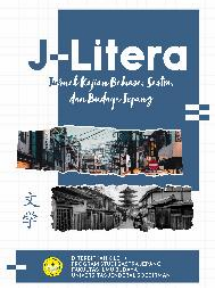

email: menik.wardani@gmail.com*

DOI: $10.20884 / 1 . j l i t e r a .2020 .2 .1 .2396$

\begin{abstract}
The title of this research is Rendaku Classification in Basic Kanji Books Volume I and Volume II. Rendaku is the change of the non-voice consonants into a voiced consonant. The purpose of this research is to classifying the consonant changes of rendaku in Japanese language. This research is a qualitative descriptive study with data collection technique using the literature study tecniques. The method of analysis in this research is the determinants element technique. There are 38 data in the form of wago containing rendaku changes. Data source taken from Basic Kanji Volume 1 and Volume 2. The results of the analysis in this research found the changes in $k \rightarrow g$ as many as 10 data, changes in $h \rightarrow b$ as many as 7 data, changes in $s / t s \rightarrow z$ as many as 4 data, changes in $t \rightarrow d$ as many as 4 data. Based on the results of the analysis can be conclude that: 1) rendaku will appears on compound words, 2) rendaku will appear if in the second morpheme there are no other voiced consonant. Rendaku happened to morphemes kawa, kami, kata, kaki, ki, kaeri, kuchi, kuni, kusuri, kuruma, ha, hatake, harai, hiki, hito, hi, hosoi, sakana, sama, tsukuri, tsuyoi, tome, toshi, tomo, tera.
\end{abstract}

Keywords:

Rendaku; morphophonemics; wago

Article Info:

First received:

24 February 2020

Available online:

30 November 2020

\section{PENDAHULUAN}

Manusia sebagai makhluk sosial tidak bisa lepas dari ketersediaan bahasa dalam kesehariannya. Bahasa telah menjadi alat komunikasi yang paling efektif untuk digunakan dalam kegiatan bermasyarakat. Menurut Kridalaksana, bahasa merupakan sebuah sistem lambang bunyi yang bersifat arbitrer yang digunakan oleh masyarakat untuk bekerja sama, berinteraksi, serta mengidentifikasi diri (Chaer, 2007:32). Tiap-tiap bahasa di dunia memiliki karakterisitiknya masing-masing sehingga membedakan satu bahasa dengan bahasa lainnya, begitu juga dengan bahasa Jepang yang memiliki karakteristik yang unik seperti huruf dan kosakatanya.

Bahasa Jepang memiliki 4 jenis kosakata berdasarkan asal-usulnya, yakni kosakata wago yang merupakan kosakata asli Jepang atau yamato kotoba, kosakata kango yang merupakan kosakata dalam bahasa Jepang yang terbentuk dari cara baca China, kosakata gairaigo yang merupakan kosakata serapan, dan kosakata konshugo yang merupakan gabungan dari beberapa unsur kosakata yang berbeda (Sudjianto, 2007:99).

Bahasa sendiri dikaji dan dipelajari melalui ilmu linguistik. Ilmu linguistik dalam bahasa Jepang disebut dengan gengogaku yang mempelajari mengenai seluk-beluk mengenai bahasa (Sutedi, 2004:2). Fonologi merupakan salah satu cabang ilmu linguistik yang mempelajari mengenai bunyi-bunyi bahasa serta bagaimana bunyi tersebut dihasilkan. Menurut Mitsuo dalam Tjandra (2004:1), fonologi merupakan ilmu yang mempelajari fungsi serta kondisi bunyi bahasa secara khusus didalam tata bunyi bahasa itu sendiri. Objek kajian dari tataran fonologi adalah fonem yang merupakan satuan bunyi terkecil yang diucapkan. Kajian lain dalam ilmu linguistik adalah morfologi. Morfologi mengkaji proses pembentukan kata dalam suatu bahasa. Objek kajian dalam tataran morfologi adalah morfem dan kata. Morfem merupakan satuan terkecil dalam ilmu bahasa yang memiliki makna, sedangkan kata merupakan satuan terkecil bahasa yang terdiri dari gabungan morfem. Kata dapat berupa kata tunggal atau kata majemuk. Dalam bahasa 
Indonesia, kata majemuk didefinisikan sebagai gabungan dari kata yang membentuk makna baru, sedangkan dalam bahasa Jepang kata majemuk didefinisikan sebagai gabungan dari dua kata atau lebih. Kata majemuk atau kata gabung dalam bahasa Jepang disebut fukugougo. Kata tegami merupakan salah satu contoh fukugougo. Tegami merupakan gabungan dari morfem te dan morfem kami, sehinggan membentuk kata tegami.

Dalam proses penggabungan kata, kadangkadang terjadi pula perubahan pada bidang morfofonemik. Morfofonemik merupakan sebuah proses fonologis yang terjadi karena adanya pertemuan antara morfem dengan morfem. Hal ini terjadi sebagai sebuah bentuk adaptasi untuk mendapatkan keserasian. Ada 7 jenis morfofonemik dalam bahasa Jepang, yakni:

1. On'in datsuraku, yaitu penghilangan fonem

2. On'in tenka, yaitu penambahan fonem

3. Onbin, asimilasi bunyi

4. Boin koutai, perubahan fonem vokal

5. Perubahan aksen

6. On'in shukuyaku, pemendekan fonem

7. Rendaku, perubahan fonem konsonan

Kata tegami merupakan salah satu bentuk hasil dari proses morfofonemik yakni, rendaku. Pada kata tegami terjadi perubahan fonem konsonan awal pada morfem kami menjadi gami. Fonem /k/ yang merupakan fonem konsonan tak bersuara berubah menjadi fonem /g/ yang merupakan fonem konsonan bersuara. Jadi, bisa disimpulkan bahwa rendaku merupakan proses perubahan fonem konsonan tak bersuara menjadi fonem konsonan bersuara yang terjadi pada konsonan pertama pada morfem kedua dalam sebuah kata majemuk.

Terdapat 5 klasifikasi jenis perubahan fonem didalam rendaku, yakni:

1. Konsonan /k/ menjadi konsonan /g/

2. Konsonan /s/ dan /ts/ menjadi konsonan /z/

3. Konsonan $/ \mathrm{t} /$ menjadi konsonan $/ \mathrm{d} /$

4. Konsonan /h/ dan /f/ menjadi konsonan /b/

5. Konsonan /sh/ dan /ch/ menjadi konsonan $/ \mathrm{j} /$

\section{TINJAUAN PUSTAKA}

\section{Fonologi}

Secara etimologi, istilah fonologi tersusun dari kata fon yang memiliki arti bunyi dan logos yang memiliki arti ilmu (Chaer, 2013:1). Pendapat lain dikemukakan oleh Kindaichi dalam Tjandra (2004:1), yang menjelaskan bahwa fonologi merupakan ilmu yang mempelajari fungsi dan kondisi bunyi-bunyi bahasa secara khusus di dalam tata bunyi bahasa yang bersangkutan berdasarkan data-data yang diperoleh dari ilmu fonetik. Secara garis besar, fonologi diartikan sebagai salah satu cabang ilmu linguistik yang mempelajari dan menganalisis bunyi-bunyi yang diproduksi oleh alat ucap manusia beserta fungsinya.

Bunyi bahasa dalam bahasa Jepang terdiri atas vokal (boin), konsonan (shi'in) dan semi vokal (hanboin).

1. Vokal atau boin merupakan bunyi bahasa yang dihasilkan dengan arus udara pernapasan yang dikeluarkan dari paru-paru melewati tenggorokan lalu keluar melewati rongga mulut (Sudjianto, 2007:27). Vokal termasuk dalam yuuseion (bunyi yang bersuara) yaitu bunyi yang dihasilkan disertai getaran pita suara. Bahasa Jepang memiliki lima macam bunyi vokal yakni, /a/, / i/, /u/, /e/, /o/.

2. Konsonan atau shin'in merupakan bunyi suara yang dibentuk oleh arus udara pernapasan yang keluar melewati pita suara yang mengalami rintangan, hambatan seperti penutupan atau penyempitan alat ucap manusia.

Ada dua macam klasifikasi konsonan, yakni:

a. Klasifikasi konsonan berdasarkan jenis rintangan, hambatan dari alat ucap (Katoo dalam Sudjianto 2007:33)

1) Ryooshin'on (bilabial) yaitu bunyi yang dikeluarkan dengan menggunakan kedua belah bibir bawah dan bibir atas. Konsonan-konsonan yang termasuk dalam kelompok ini adalah konsonan $/ \mathrm{m} /, / \mathrm{p} /, / \mathrm{b} /, / \mathrm{f} /$.

2) Ha-Hagukion (dental-alveolar), yaitu bunyi yang dikeluarkan menggunakan alat ucap antara gigi atas dan gusi dengan ujung lidah. Konsonankonsonan yang termasuk dalam kelompok ini adalah konsonan $/ \mathrm{s} /$, $/ \mathrm{z} /, / \mathrm{r} /, / \mathrm{n} /, / \mathrm{t} /, / \mathrm{d} /$.

3) Shikei kookoogaion (alveolar-palatal), yaitu bunyi yang dikeluarkan 
menggunakan alat ucap antara gusi dan langit-langit keras dengan lidah bagian depan. Konsonan-konsonan yang termasuk dalam kelompok ini adalah konsonan-konsonan pada suku kata shi, ji, chi.

4) Kookoogaion (palatal), yaitu bunyibunyi yang dikeluarkan dengan menggunakan langit-langit keras dengan lidah bagian tengah. Konsonan-konsonan yang termasuk dalam kelompok ini adalah konsonan pada silabel $h i$ dan $n i$.

5) Nankoogoin (velar), yaitu bunyi yang dikeluarkan dengan menggunakan langit-langit lunak dengan lidah bagian belakang. Konsonan-konsonan yang termasuk dalam kelompok ini adalah konsonan pada silabel ka, ga, nga serta konsonan /N/.

6) Seimon'on (glotal), yaitu bunyi yang keluar dari celah yang sempit diantara kedua pita suara. Konsonan-konsonan yang termasuk dalam kelompok ini adalah konsonan /h/.

b. Klasifikasi konsonan berdasarkan caracara keluar arus udara pernapasan (Iwabuchi dalam Sudjianto, 2007:34).

1) Konsonan Letup

Konsonan letup terjadi ketika hambatan penuh, arus udara berenergi besar mengalir dari paru-paru untuk memecahkan tersebut. Bunyi letupan terjadi saat hambatan dipecahkan. Konsonan yang termasuk dalam kelompok ini adalah konsonan $/ \mathrm{p} /$, $/ \mathrm{b} /, / \mathrm{t} /, / \mathrm{d} /, / \mathrm{k} /, / \mathrm{g} /, / \mathrm{l} /$.

2) Konsonan Frikatif

Konsonan frikatif terjadi ketika hambatan yang terjadi hanya sebagian. Arus udara dari paru-paru yang mengalir lewat hambatan sebagian itu saling bergesekan sehingga menimbulkan suara desis. Konsonan yang termasuk dalam kelompok ini adalah konsonan /s/, /h/, /f/, / j/, $\mathrm{z} / \mathrm{s}$.

3) Konsonan Afrikat

Konsonan afrikat ini berhambat sebagian. Hambatan sebagian pada praucapan itu bersifat agak kuat sehingga arus udara yang mengalir dari paru-paru saling berdesakan memecah hambatan itu dan menghasilkan suara letupan kecil bercampur suara gesekan. Konsonan yang termasuk dalam kelompok ini adalah konsonan pada silabel chi, tsu.

4) Konsonan Nasal

Konsonan nasal terjadi ketika ada hambatan penuh di rongga mulut sehingga arus udara yang dikeluarkan dari paru-paru akan keluar melalui rongga hidung. Konsonan yang termasuk dalam kelompok ini adalah konsonan /m/, /n/, /n/, dan konsonan pada silabel $n g a, n g i, n g u, n g e$, ngo.

5) Konsonan Likwida

Konsonan likwida adalah konsonan yang tercipta dengan mengangkat ujung lidah menempel pada gusi dan arus udara dialirkan pada titik hambatan itu. Konsonan likwida terbagi menjadi tiga yakni, lateral yang dihasilkan dengan menempelkan ujung lidah pada lengkung gigi tanpa digetarkan sama sekali dan diberi tanda fonetis $/ 1 /$; tril yang dihasilkan dengan cara ujung lidah ditempelkan pada lengkung gigi kemudian menggetarkan ujung lidah berkali-kali dan diberi tanda fonetis / $\mathrm{r}$; flap yang dihasilkan dengan cara menggetarkan ujung lidah yang diletakkan pada lengkung gigi sebanyak satu kali dan diberi tanda fonetis $/ \mathrm{r} /$.

Selain itu, konsonan terbagi menjadi konsonan bersuara dan konsonan tidak bersuara. Konsonan bersuara dihasilkan karena adanya getaran pada pita suara ketika arus udara keluar dari paru-paru, sedangkan konsonan tak bersuara dihasilkan karena tidak adanya getaran pada pita suara ketika arus udara keluar dari paru-paru. Yang termasuk kedalam deretan konsonan bersuara adalah fonem /b/, /d/, /g/, dan $/ \mathrm{z} /$, sedangkan fonem yang termasuk kedalam deretan konsonan tak bersuara adalah fonem $/ \mathrm{p} /, / \mathrm{t} /, / \mathrm{k} /, / \mathrm{s} /, / \mathrm{h} /, / \mathrm{c} /$, dan $/ \Phi /$ (Tjandra, 2004:111).

Selain bunyi hahasa, fonologi juga mengkaji mengenai fonem. Fonem atau onso dikaji dalam fonemik yang mempelajari fungsi serta kedudukan dari masing-masing bunyi bahasa di dalam tata bahasa. Menurut Chaer, fonem merupakan satuan bunyi bahasa yang 
membedakan makna atau arti. Pedapat serupa datang dari Tjandra yang menyatakan bahwa fonem merupakan satuan bunyi terkecil berwujud abstrak dengan ciri pembeda fonetis yang berfungsi membedakan makna dalam bahasa lisan dan merupakan kristalisasi dari beberapa bunyi kongkrit. Fonem dalam bahasa Jepang terdiri dari empat macam seperti berikut.
1. Vokal (V)
: /a, i, u, e, o/

2. Konsonan (C) : /k, g, s, z, t, d, c, n, h, p, b, $\mathrm{m}, \mathrm{r}, \Phi /$

3. Semi vocal (Sv) : $/ \mathrm{w}, \mathrm{j} /$

4. Fonem khusus : /Q, N, R/

Dalam bahasa Jepang terdapat fonem khusus yang dilambangkan dengan $/ \mathrm{Q} /, / \mathrm{N} /$, /R/. Fungsi fonem /Q/ digunakan untuk menyatakan konsonan rangkap atau sokuon, fonem /N/ sebenarnya digunakan untuk melambangkan huruf /n/ dan berbagai variannya, dan fonem / $\mathrm{R} /$ merupakan lambang bunyi vokal panjang yang dalam tanda fonetik ditulis dengan [:]. Fonem /z/ dalam bahasa Jepang terdiri dari bunyi $[\mathrm{dz}]$ dan $[\mathrm{z}]$, kedua bunyi tersebut merupakan satu fonem. Dalam satu fonem memunculkan beberapa bunyi akibat letak fonem tersebut dalam suatu kata, yang dipengaruhi oleh fonem yang ada didepan atau dibelakangnya (Sutedi, 2004:39).

Setiap bunyi dalam bahasa Jepang ditulis dengan huruf kana, setiap satu hurufnya dianggap sebagai satu mora atau ketukan. Kata びよういん biyouin 'salon kecantikan' terdiri dari lima huruf dan dianggap sebagai lima mora. Tetapi pada kata びょういん byouin 'rumah sakit', meskipun terdiri atas lima huruf hiragana tertapi terdiri atas empat mora karena びょう byo merupakan satu bunyi. Sedangkan silabel dalam bahasa Jepang disebut onsetsu atau suku kata. Banyaknya huruf kana yang digunakan dalam suatu kata tidak sama dengan jumlah silabel dalam kata tersebut. Misalnya びょうい ん byouin 'rumah sakit' yang hanya memiliki dua silabel yaitu びょう byou dan いん in (Sutedi, 2003:41).

\section{Morfologi}

Morfologi mempelajari seluk beluk bentuk kata serta pengaruh perubahan-perubahan bentuk kata terhadap golongan dan arti kata serta fungsi perubahan-perubahan bentuk kata itu baik fungsi gramatik maupun fungsi semantik. Dalam kaitannya dengan kebahasaan, yang dipelajari dalam morfologi ialah bentuk kata. Selain itu, perubahan kata dan makna yang muncul serta perubahan kelas kata yang disebabkan perubahan bentuk kata itu, juga menjadi objek pembicaraan dalam morfologi.

Morfem adalah unsur-unsur terkecil yang memiliki makna dalam ujaran suatu bahasa (Hookett, 1958:123 dalam Tarigan, 1985:6). Dalam bahasa Jepang, morfem disebut keitaiso yang merupakan satuan bahasa terkecil yang memiliki makna dan tidak bisa dipecahkan lagi (Sutedi, 2003:43). Dalam bahasa Jepang, morfem terbagi menjadi dua yakni:

1) Morfem bebas

Morfem bebas atau jiyuu keitaiso merupakan morfem yang secara potensial bisa berdiri sendiri dan memiliki arti. Contohnya pada kata migite yang terdiri dari dua morfem yakni migi dan te yang bermakna tangan kanan. Morfem migi dan te masingmasing bisa berdiri sendiri dan memiliki makna yakni kanan dan tangan.

2) Morfem Terikat

Morfem terikat atau kousouku keitaiso merupakan morfem yang tidak bisa berdiri sendiri. Contohnya terdapat pada kata samusa yang terdiri atas morfem samu dan morfem sa. Morfem sa merupakan morfem terikat karena morfem $s a$ tidak memiliki makna saat berdiri sendiri.

Selain morfem, objek kajian lain dalam morfologi adalah kata atau go. Kata merupakan satuan bebas yang paling kecil. Kata merupakan satuan bahasa yang lebih besar dari morfem. Definisi kata menurut Kridalaksana (1993:98), kata adalah satuan bahasa yang dapat berdiri sendiri, terbentuk dari morfem tunggal atau gabungan dari morfem. Kata di dalam bahasa Jepang terbagi menjadi beberapa kelas kata sebagai berikut.

\section{1) Doushi 'Verba'}

Doushi merupakan kata yang digunakan untuk menjalankan aktivitas, keberadaan atau keadaan sesuatu. Kata yang termasuk verba bisa mengalami perubahan dan dengan sendirinya dapat menjadi predikat.

2) I-keiyoushi 'Adjektiva I' 
I-keiyoushi merupakan kelas kata yang menyatakan sifat atau keadaan sesuatu, dengan sendirinya dapat menjadi predikat dan dapat mengalami perubahan bentuk. Kata yang termasuk i-keiyoushi selalu diakhiri dengan silabel /i/.

3) Na-keiyoushi 'Adjektiva $\mathrm{Na}$ '

Na-keiyoushi merupakan kelas kata yang menyatakan sifat dengan sendirinya dapat berubah bentuk dengan bentuk perubahannya berakhiran $d a$ atau desu.

4) Meishi 'Nomina'

Meishi merupakan kelas kata yang menyatakan orang, benda peristiwa, dan sebagainya. Meishi tidak mengalami konjugasi, dan dapat dilanjutkan dengan kakujoshi.

5) Rentaishi 'Prenomina'

Rentaishi merupakan kelas kata yang termasuk kelompok jiritsugo yang tidak mengenal konjugasi dan digunakan hanya untuk menerangkan nomina.

6) Fukushi 'Adverbia'

Fukushi merupakan kelas kata yang tidak mengalami perubahan bentuk dan dengan sendirinya dapat menerangkan verba, adjektiva, yang berfungsi menyatakan keadaan atau derajat aktivitas, atau suasana dan perasaan pembicara.

7) Kandoushi 'Interjeksi'

Kandoushi merupakan kelas kata yang tidak dapat berubah bentuk, tidak dapat menjadi subjek dan tidak mengalami konjungsi. Tapi kelas kata ini bisa berdiri sendiri walaupun tanpa bantuan kelas kata lain.

8) Setsuzokushi 'konjungsi'

Setsuzokushi merupakan kelas kata yang berfungsi untuk menyambungkan antar kalimat atau menggabungkan antar bagian kalimat.

9) Jodoushi 'Verba bantu' Jodoushi merupakan keas kata yang dapat berubah bentuk. Kata ini tidak dapat berdiri sendiri, tetapi harus digabungkan terlebih dahulu dengan kata lain.

10) Joshi 'Partikel'
Joshi adalah kelas kata yang tidak dapat berdiri sendiri yang dipakai setelah suatu kata untuk menunjukkan hubungan antara kata tersebut dengan kata lain.

Pembentukan kata dalam bahasa Jepang atau yang disebut dengan proses morfologis terjadi dari tiga proses, yaitu proses pemajemukan atau fukugougo, proses reduplikasi atau juufuku, dan proses derivasi atau haseigo.

1) Fukugougo 'Kata Majemuk'

Fukugougo merupakan proses pemajemukan atau komposisi. Menurut Sutedi (2003:46), fukugougo merupakan kata yang terbentuk dari hasil penggabungan beberapa morfem isi. Secara struktur komposisi dapat dilihat dari jenis kata unsur pembentuk pemajemukan yang terdiri dari:

a. Nomina + Verba $=$ Nomina yama + aruki $=$ yamaaruki

'gunung' 'berjalan' 'jalanjalan di gunung'

b. Verba + Verba $=$ Verba aruku + mawaru = arukumawaru

'berjalan' 'memutar' 'berkeliling'

c. Adjektiva (na) + Verba = Nomina

kirei +suki =

kireizuki

'indah' 'menyukai' 'suka kebersihan'

d. Adjektiva (i) + Verba $=$ Nomina chikai +yoru chikayoru 'dekat' 'mengunjungi' 'mendekat'

e. Adverbia + Verba $=$ Nomina garagara + warau = garagarawarau 'goyah' 'tertawa' 'tertawa terbahak-bahak'

f. Nomina + Adjektiva (na) $=$ Nomina Adjektiva

mono + suki = monozuki

'hal' 'aneh' 'iseng' 


g. Nomina + Adjektiva (i) =
Adjektiva (i)
hara + kuroi =
haraguroi
'pemikiran' 'hitam'
'berhati busuk'

2) Reduplikasi

Reduplikasi atau pengulangan dalam bahasa Jepang dikenal dengan istilah juufuku (Sunarni, 2016:50). Ada dua jenis reduplikasi dalam bahasa Jepang, yakni:

a. Reduplikasi jamak, pengulangan nomina untuk menunjukkan jamak. yama 'gunung' + yama 'gunung'

= yamayama 'gunung-gunung'

b. Reduplikasi dengan sinomin atau antonim unsur pertama. osokare 'lambat' + hayakare 'cepat' = osokarehayakare 'cepat atau lambat'

3) Derivasi

Derivasi atau haseigo merupakan proses pembentukan kata yang menghasilkan leksem baru. Derivasi dalam bahasa Jepang terjadi melalui proses prefiksasi atau sufiksasi (Sunarni, 2016:54).

1. Prefiksasi merupakan proses penambahan prefix atau awalan terhadap kata yang dilekatinya sehingga dapat mengubah makna kata atau memberikan sifat pada kata yang ditempelinya.

oo 'besar' + jishin 'gempa' = oojishin 'gempa besar'

2. Sufiksasi merupakan proses penambahan sufiks atau akhiran pada kata yang dilekatinya. Sama halnya dengan prefiksasi, sufiksasi pun bisa mengubah makna ataupun jenis kata.

utsukushi 'cantik' $+s a=$ utsukushisa 'kecantikannya'

\section{Morfofonemik}

Morfofonemik merupakan cabang linguistik yang muncul akibat terjadinya pengaruh dari faktor-faktor fonologis atau faktor gramatikal yang berperan dalam pemunculan fonem. Kridalaksana (2007:183) memaparkan bahwa morfofonemik merupakan proses fonologis yang terjadi karena pertemuan morfem dengan morfem. Morfofonemik juga mengacu pada struktur bahasa yang menggambarkan pola fonologis dari morfem seperti penambahan, pengurangan atau penggantian fonem. Hal ini juga sejalan dengan yang dikemukakan Parera (1994:41) yang mengatakan bahwa gejala morfofonemik timbul apabila fonem-fonem yang bersinggungan dan mengalami perubahan bunyi karena pengaruh lingkungan yang dimiliki oleh tiap morfem.

Suzuki dalam Sunarni (2016:47) menyatakan bahwa dalam bahasa Jepang, perubahan fonem dalam proses morfofonemik ada 7, yaitu:

a. Perubahan aksen

Contoh: $o+$ kusuri 'obat' $\rightarrow$ okusuri 'obat'

b. On'in datsuraku atau pelesapan fonem

Contoh: kawa 'sungai' + hara 'padang' $\rightarrow$ kawara 'dataran pinggir sungai'

c. On'in shukuyaku atau penyingkatan fonem

Proses pemendekan bunyi fonemis sebagai akibat dari pemendekan pengucapan.

Contoh: te 'tangan' + aria 'mencuci' $\rightarrow$ tarai 'tempat cuci tangan'

d. On'in tenka atau penambahan fonem

Proses penambahan posisi fonem terjadi apabila dalam penggabungan morfem dasar muncul fonem baru.

Contoh: haru 'musim semi' + ame 'hujan' $\rightarrow$ harusame 'hujan musim semi'

e. Boin koutai atau perubahan vokal

Proses perubahan vokal terjadi ketika dua kata digabungkan untuk menjadi kata majemuk maka vokal terakhir pada kata pertama berubah.

Contoh: $h i$ 'api' $\quad+$ naka 'tengah' $\rightarrow$ honaka 'tengah api' se 'punggung' + muku 'menghadap' $\rightarrow$ somuku 'membelakangi'

f. Onbin atau asimilasi bunyi

Proses perubahan bunyi menjadi bunyi nasal.

Contoh: tsuki 'serangan' + saku 'merusak' $\rightarrow$ tsunzaku 'menusuk'

g. Rendaku

Proses perubahan fonem dari seion atau bunyi konsonan tak bersuara menjadi dakuon yakni konsonan bersuara.

Contoh: ama 'hujan' + kasa 'payung' $\rightarrow$ amagasa 'payung hujan' 


\section{Rendaku}

Rendaku 連濁 atau yang biasa disebut dengan sequential voicing merupakan salah satu proses morfofonemik yang ada di dalam bahasa Jepang. Menurut Martin dalam Vance (2011), rendaku mengacu pada fenomena morfofonemik yang ditemukan pada sebuah senyawa yang mengacu pada kata majemuk serta kombinasi dari prefiks dan akar kata. Sebuah morfem yang menunjukkan rendaku memiliki satu alomorf yang di awali dengan bunyi tak bersuara dan alomorf lainnya di awali dengan bunyi bersuara. Bunyi yang terlibat di dalam rendaku merupakan bunyi konsonan. Hal ini sejalan dengan yang dikemukakan oleh Ito dan Mester (2003:71) yakni bahwa rendaku terjadi ketika fonem awal pada morfem kedua disuarakan. Contohnya pada kata. Intinya, bunyi rendaku berfokus pada morfem kedua dalam sebuah kata majemuk. Ito dan Mester juga menjelaskan bahwa rendaku terjadi karena adanya kombinasi antara struktur morfologis yang dipersempit oleh pembatasan fonologis dan ditambah dengan perubahan struktural fonologis.

Yamaguchi dalam Minami (2011:115) mengatakan bahwa rendaku tidak bisa dianggap sebagai proses fonologis biasa dikarenakan adanya banyak pengecualian yang disebabkan oleh beberapa faktor. Faktor yang terpenting adalah faktor fonologis yang disebut dengn Lyman's Law. Seperti yang dijelaskan oleh Vance (2007), Lyman's Law menjelaskan bahwa morfem kedua dalam sebuah kata majemuk yang mengandung konsonan bersuara pada bagian tengahnya tidak akan mengalami rendaku. Contoh:

\section{kami 'dewa' + kaze 'angin' =}

kamikaze 'angin dewa'

Pada kata kamikaze, konsonan tak bersuara /k/ pada / kaze/ tidak mengalami perubahan menjadi konsonan bersuara karena sudah mengandung konsonan bersuara /z/. Pengecualian fonologis lainnya dikemukakan oleh McCawley dalam Minami (2011: 114), rendaku tidak akan terjadi apabila fonem terakhir pada morfem pertama dalam kata majemuk bukan vokal, tetapi terkadang rendaku bisa terjadi apabila fonem terakhir pada morfem pertama merupakan fonem nasal.

Faktor lainnya berupa faktor leksikal yang berhubungan dengan usul kata. Shibatani dalam Minami (2011:115) menyatakan bahwa rendaku hanya terjadi pada kata asli bahasa Jepang, dan tidak terjadi pada kata pinjaman. Selain itu, faktor morfologis yang ada pada rendaku berkaitan dengan struktur kata. Yamaguchi mengatakan bahwa rendaku hanya terjadi pada senyawa yang terdiri dari dua atau lebih kata independen dan tidak terjadi pada kata derivasi. Selain itu, rendaku juga terjadi pada bentuk reduplikasi.

Vance (2016:1) menjabarkan salah satu contoh rendaku pada /teral /dera/ yang muncul dengan konsonan / $\mathrm{t} / \mathrm{pada}$ kata /tera/ 'kuil'. Konsonan /t/ yang sama juga muncul pada kata majemuk /tera + otoko/, tapi konsonan /d/ muncul pada senyawa /ama+dera/. Hal tersebut menunjukkan bahwa alomorf yang dimulai dengan konsonan tak bersuara hanya bisa muncul pada komponen kedua didalam kata majemuk. Konsonankonsonan yang bisa mengalami rendaku adalah sebagai berikut.

\section{Kunrei $^{1}$ Hepburn $^{2}$}
a. $/ \mathrm{f} / \rightarrow / \mathrm{b} /[\phi]:[\mathrm{b}]$
$\mathrm{h} \rightarrow \mathrm{b}$
$\mathrm{f} \rightarrow \mathrm{b}$
b. $/ \mathrm{h} / \rightarrow / \mathrm{b} /$
[h][ç] : [b] $\mathrm{h} \rightarrow \mathrm{b}$
$\mathrm{h} \rightarrow \mathrm{b}$
c. $/ \mathrm{t} / \rightarrow / \mathrm{d} /[\mathrm{t}]:[\mathrm{d}]$
$\mathrm{t} \rightarrow \mathrm{d}$
$\mathrm{t} \rightarrow \mathrm{d}$
d. $/ \mathrm{c} / \rightarrow / \mathrm{z} / \underset{\mathrm{ts} \rightarrow \mathrm{z}}{[\mathrm{ts}]:[\mathrm{dz}]}$
$t \rightarrow z$
e. $/ \check{c} / \rightarrow / \check{\mathrm{j}} / \quad\left[\mathrm{t}_{6}\right]:[\mathrm{d} z]$
$t \rightarrow z$
$\mathrm{ch} \rightarrow \mathrm{j}$
f. $/ \mathrm{s} / \rightarrow / \mathrm{z} / \quad[\mathrm{s}]:[\mathrm{dz}]$
$\mathrm{s} \rightarrow \mathrm{Z}$
$\mathrm{s} \rightarrow \mathrm{Z}$
g. $/ \check{\mathrm{s}} / \rightarrow / \mathrm{j} /$
$[6]:[\mathrm{d} z]$
$\mathrm{s} \rightarrow \mathrm{Z}$
$\mathrm{sh} \rightarrow \mathrm{j}$
h. $/ \mathrm{k} / \rightarrow / \mathrm{j} /$
$[\mathrm{k}]:[\mathrm{g}]([\mathrm{y}])$
$\mathrm{k} \rightarrow \mathrm{g}$
$\mathrm{k} \rightarrow \mathrm{g}$

Sehingga bisa disimpulkan bahwa klasifikasi perubahan konsonan pada rendaku adalah sebagai berikut.

1. Konsonan /k/ menjadi konsonan /g/

2. Konsonan /s/ dan /ts/ menjadi konsonan $/ \mathrm{z} /$

3. Konsonan $/ \mathrm{t} /$ menjadi konsonan $/ \mathrm{d} /$

4. Konsonan /h/ dan /f/ menjadi konsonan /b/

5. Konsonan /sh/ dan /ch/ menjadi konsonan $/ \mathrm{j}$ / 


\section{METODE PENELITIAN}

Penelitian ini adlah penelitian deskriptif kualitatif. Bentuk penelitian terurai berupa katakata atau gambar yang diperlukan bukan berupa angka. Laporan penelitian ini akan berisi mengenai kutipan-kutipan data untuk memberi suatu gambaran penyajian laporan.

Data dalam penelitian ini berupa kosakata wago yang mengandung bunyi rendaku. Sumber data berupa buku Basic Kanji volume I dan volume II. Teknik pengumpulan data pada penelitian ini adalah teknik studi pustaka. Menurut Sugiyono, studi pustaka berkaitan dengan kajian teoritis dan referensi lain yang berkaitan dengan literatur-literatur ilmiah (Sugiyono, 2012:291). Teknik analisis pada penelitian ini menggunakan teknik pilah unsur penentu dimana konsonan-konsonan yang mengalami perubahan bunyi yang menjadi unsur penentunya lalu menjabarkan bagaimana proses perubahan yang terjadi dengan menggunakan teori yang ada.

\section{HASIL DAN PEMBAHASAN}

Hasil dan pembahasan memaparkan mengenai klasifikasi perubahan-perubahan rendaku yang terkandung dalam kosakata wago. Data berupa kosakata wago yang mengandung rendaku. Berikut adalah hasil analisis klasifikasi rendaku pada kosakata wago berdasarkan perubahannya, terdapat 38 data yang terbagi berdasarkan klasifikasi perubahannya yaitu:

1) Perubahan konsonan $/ \mathrm{k} /$ menjadi konsonan /g/

\section{1. まどぐち madoguchi 'loket'}

Pada data madoguchi 'loket' merupakan gabungan dari dua morfem isi yaitu morfem mado 'jendela' yang merupakan verba dan morfem kuchi 'mulut' yang merupakan nomina. Proses penggabungan morfem tersebut menyebabkan terjadinya proses morfofonemik. Perubahan tersebut terjadi pada fonem awal pada morfem kuchi 'mulut', yakni dari fonem $/ \mathrm{k} /$ menjadi fonem /g/.

Morfem yang memiliki bunyi hambat bersuara di bagian tengah, tidak akan mengalami rendaku. Pada kata madoguchi 'loket', bagian tengah pada morfem kuchi 'mulut' adalah fonem /ch/ yang merupakan konsonan afrikat. Oleh karena itu, fonem /k/ dari morfem kuchi 'mulut' yang merupakan konsonan letup tak bersuara berubah menjadi fonem /g/ yang merupakan konsonan letup bersuara.

2) Perubahan konsonan /t/ menjadi konsonan /d/

1.いたみどめ itamidome 'pereda nyeri'

Pada data itamidome 'pereda nyeri' merupakan gabungan dari dua morfem isi yaitu morfem itami 'sakit' yang merupakan nomina dan morfem tome 'menghentikan' merupakan verba. Proses penggabungan morfem tersebut menyebabkan terjadinya proses morfofonemik. Perubahan tersebut terjadi pada fonem awal pada morfem tome 'menghentikan', yakni dari fonem / $\mathrm{t} /$ menjadi fonem / $\mathrm{d} /$.

Morfem yang memiliki bunyi hambat bersuara di bagian tengah, tidak akan mengalami rendaku. Pada kata itamidome 'pereda nyeri', bagian tengah pada morfem tome 'menghentikan' adalah fonem $/ \mathrm{m} /$ yang merupakan konsonan nasal. Oleh karena itu, fonem /t/ pada morfem tome 'menghentikan' yang merupakan konsonan letup tak bersuara berubah menjadi fonem /d/ yang merupakan konsonan letup bersuara.

3) Perubahan konsonan /s/ dan /ts/ menjadi konsonan /z/

1. やきざかな yakizakana 'ikan bakar'

Pada data yakizakana ikan bakar' merupakan gabungan dari dua morfem isi yaitu morfem yaki 'membakar' yang merupakan verba dan morfem sakana 'ikan' yang merupakan nomina. Proses penggabungan morfem tersebut menyebabkan terjadinya proses morfofonemik. Perubahan tersebut terjadi pada fonem awal pada morfem sakana 'ikan', yakni dari fonem /s/ menjadi fonem $/ \mathrm{z} /$. 
Morfem yang memiliki bunyi hambat bersuara di bagian tengah, tidak akan mengalami rendaku. Pada kata yakizakana 'ikan bakar', bagian tengah pada morfem sakana 'ikan' merupakan fonem $/ \mathrm{k} /$ yang merupakan konsonan letup tak bersuara. Oleh karena itu, fonem /s/ pada morfem sakana 'ikan' yang merupakan konsonan frikatif tak bersuara berubah menjadi fonem /z/ yang merupakan konsonan frikatif bersuara.

(BK.I.62)

2. にづくり nizukuri 'mengemas barang'

Pada data nizukuri 'mengemas barang' merupakan gabungan dari dua morfem isi yaitu morfem ni 'barang' yang merupakan nomina dan morfem tsukuri 'membuat' yang merupakan verba. Proses penggabungan morfem tersebut menyebabkan terjadinya proses morfofonemik. Perubahan tersebut terjadi pada fonem awal pada morfem tsukuri 'membuat', yakni fonem /ts/ menjadi fonem $/ \mathrm{z} /$.

Morfem yang memiliki bunyi hambat bersuara di bagian tengah, tidak akan mengalami rendaku. Pada kata nizukuri 'mengemas barang', bagian tengah pada morfem tsukuri 'membuat' merupakan fonem $/ \mathrm{k} /$ yang merupakan konsonan letup tak bersuara. Oleh karena itu, fonem /ts/ pada morfem tsukuri 'membuat' yang merupakan konsonan afrikat tak bersuara berubah menjadi fonem /z/ yang merupakan konsonan frikatif bersuara.

4) Perubahan konsonan $/ \mathrm{h} /$ menjadi konsonan /b/

\section{1. わりびき waribiki 'potongan harga'}

Pada data waribiki 'potongan harga' merupakan gabungan dari dua morfem isi yaitu morfem wari 'per-sepuluh bagian' yang merupakan nomina dan morfem hiki 'memotong' yang merupakan verba. Proses penggabungan morfem tersebut menyebabkan terjadinya proses morfofonemik. Perubahan tersebut terjadi pada fonem awal pada hiki 'memotong', yakni dari fonem /h/ menjadi fonem /b/.

Morfem yang memiliki bunyi hambat bersuara di bagian tengah, tidak akan mengalami rendaku. Pada kata wairibiki 'potongan harga', bagian tengan pada morfem hiki 'memotong' adalah fonem /k/ yang merupakan konsonan letup tak bersuara. Oleh karena itu, fonem $/ \mathrm{h} /$ dari morfem hiki 'memotong' yang merupakan konsonan frikatif tak bersuara berubah menjadi fonem /b/ yang merupakan konsonan letup bersuara.

(BK.II.111)

Selain pada kata majemuk, rendaku juga terjadi pada bentuk reduplikasi sebagai berikut.

1) くにぐに kuniguni 'negara-negara'

Pada data kuniguni 'negaranegara'merupakan bentuk reduplikasi penuh dari morfem kuni 'negara' yang memiliki arti negara. Reduplikasi penuh menunjukkan bentuk jamak, sehingga menjadi kuniguni 'negara-negara'. Reduplikasi tersebut juga menyebabkan terjadinya proses morfofonemik. Perubahan tersebut terjadi pada fonem $/ \mathrm{k} /$ pada pengulangan kata kuni, yakni dari fonem /k/ menjadi fonem /g/.

Morfem yang memiliki bunyi hambat bersuara di bagian tengah, tidak akan mengalami rendaku. Pada kata reduplikasi kuniguni 'negara-negara', bagian tengah pada morfem kuni 'negara' mengandung fonem /n/ yang merupakan konsonan nasal. Oleh karena itu, fonem / $/ \mathrm{k} /$ dari morfem kuni 'negara' yang merupakan konsonan letup tak bersuara berubah menjadi fonem /g/ yang merupakan konsonan letup bersuara.

(BK.I.193)

\section{2)さまざま samazama 'macam-macam'}

Pada data samazama merupakan bentuk reduplikasi penuh dari morfem sama yang memiliki arti Tuan atau Nyonya. Reduplikasi penuh menunjukkan bentuk jamak, sehingga menjadi samazama 'bermacam-macam'. 
Reduplikasi penuh tersebut juga menyebabkan terjadinya proses morfofonemik. Perubahan tersebut terjadi pada fonem /s/ pada pengulangan kata sama, yakni dari fonem /s/ menjadi fonem /z/.

Morfem yang memiliki bunyi hambat bersuara di bagian tengah, tidak akan mengalami rendaku. Pada kata reduplikasi samazama 'macam-macam', bagian tengah pada morfem sama mengandung fonem $/ \mathrm{m} /$ yang merupakan konsonan nasal. Oleh karena itu, fonem /s/ dari morfem sama yang merupakan konsonan frikatif tak bersuara berubah menjadi fonem / $\mathrm{z}$ / yang merupakan konsonan frikatif bersuara.

(BK.I.193)

3)ひとびと hitobito 'orang-orang'

Pada data hitobito 'orang-orang' merupakan bentuk reduplikasi penuh dari morfem hito 'orang' yang memiliki arti orang. Reduplikasi penuh menunjukkan bentuk jamak, sehingga menjadi hitobito 'orangorang'. Reduplikasi penuh tersebut juga menyebabkan terjadinya proses morfofonemik. Perubahan tersebut terjadi pada fonem $/ \mathrm{h} /$ pada pengulangan kata hito 'orang', yakni dari fonem $/ \mathrm{h} /$ menjadi fonem $/ \mathrm{b} /$.

Morfem yang memiliki bunyi hambat bersuara di bagian tengah, tidak akan mengalami rendaku. Pada kata reduplikasi hitobito 'orang-orang', bagian tengah morfem hito 'orang' mengandung fonem / $\mathrm{t} /$ yang merupakan konsonan letup tak bersuara. Oleh karena itu, fonem $/ \mathrm{h} /$ dari morfem hito yang merupakan konsonan frikatif tak bersuara berubah menjadi fonem /b/ yang merupakan konsonan letup bersuara.

(BK.II.126)

\section{KESIMPULAN}

Berdasarkan hasil analisis mengenai klasifikasi rendaku dalam buku ajar mata kuliah Hyouki yang digunakan oleh Prodi Sastra Jepang Fakultas Ilmu Budaya, Universitas Jenderal Soedirman, ditemukan 38 data yang mengandung perubahan yang diklasifikasikan menjadi 4 perubahan, yakni sebagai berikut.
1. Konsonan /k/ menjadi konsonan /g/

2. Konsonan /s/ dan /ts/ menjadi konsonan /z/

3. Konsonan /t/ menjadi konsonan /d/

4. Konsonan /h/ dan /f/ menjadi konsonan /b/

Ditemukan 25 morfem yang mengalami perubahan rendaku. Rendaku terjadi pada morfem kawa, kami, kata, kaki, ki, kaeri, kuchi, kuni, kusuri, kuruma, ha, hatake, harai, hiki, hito, hi, hosoi, sakana, sama, tsukuri, tsuyoi, tome, toshi, tomo, tera. Morfemmorfem yang merupakan morfem kedua pada kata majemuk tersebut tidak mengandung bunyi hambat bersuara di bagian tengahnya, sehingga mengalami rendaku ketika digabungkan dengan morfem lainnya.

\section{DAFTAR PUSTAKA}

Chaer, Abdul. 2007. Linguistik Umum. Jakarta: Rineka Cipta.

2013. Fonologi Bahasa Indonesia.

Jakarta: Rineka Cipta.

Kridalaksana, Harimurti. 2009. Pembentukan Kata dalam Bahasa Indonesia. Jakarta: Gramedia.

Minami, Sayoko dan Bruce Horton, 2011, "Vowel Length and Rendaku" dalam The Journal of Kanda University of Internal Studies, Vol. 23 nomor113-134).

Sudjianto \& Dahidi. 2007. Pengantar Lingustik Bahasa Jepang. Jakarta: Kesaint Blanc.

Sugiyono. 2012. Metode Penelitian Kualitatif dan $R \& D$. Bandung: Alfabeta.

Sunarni, Nani dan Johana. 2016. Morfologi Bahasa Jepang. Bandung: Unpad Press.

Sutedi, Dedi. 2003. Dasar-Dasar Linguistik Bahasa Jepang. Bandung:Humaniora Utama Press.

Vance, Timothy J. 1987. "Rendaku in Inflected Words", dalam Voicing in Japanese, diedit oleh Jaroen van de Weijer dan Tetsuo Nishihara. Berlin: Mouton de Gruyter.

2015."Rendaku", dalam Haruo Kubozono, Handbooks of Japanese 
Language and Linguistics, Walter de Gryuter Inc, Berlin.

2016. Sequential Voicing In Japanese. Philadelphia: Johns Benjamin Publishing Company.

Verhaar, J.W.M.1984. Pengantar Linguistik. Yogyakarta:Gajah Mada University Press. 